\title{
Effect of COVID-19 Pandemic on the Performance of Small and Medium Business Enterprises in Abuja-FCT, Nigeria
}

\author{
Ozigi Emmanuel Enesi, Umar Abbas Ibrahim \\ Department of Business Administration, Nile University of Nigeria, Abuja, Nigeria \\ Email: ozigienesi2002@yahoo.com, Abbas.ibrahim@nileuniversity.edu.ng
}

How to cite this paper: Enesi, O. E., \& Ibrahim, U. A. (2021). Effect of COVID-19 Pandemic on the Performance of Small and Medium Business Enterprises in Abuja-FCT, Nigeria. Open Journal of Business and Management, 9, 2261-2276. https://doi.org/10.4236/ojbm.2021.95122

Received: July 10, 2021

Accepted: September 10, 2021

Published: September 13, 2021

Copyright $\odot 2021$ by author(s) and Scientific Research Publishing Inc. This work is licensed under the Creative Commons Attribution International License (CC BY 4.0).

http://creativecommons.org/licenses/by/4.0/

(c) (i) Open Access

\begin{abstract}
It is obvious that corona virus pandemic has seriously disrupted the world economy and continuing to ravage the existence of businesses. The small and medium businesses are worst hit. This study specifically identifies the effect of COVID-19 pandemic on the performance of SMEs business in Abuja and providing recommendations on how their businesses can improve and perform effectively during this falling economy and the numerous challenges caused by the pandemic. The study adopted a quantitative research technique using data collection method through the administration of structured questionnaire and on 10 selected SMEs with 100 respondents in Municipal Area Council in Abuja which were selected purposively to elicit insights into the effect of COVID-19 pandemic on their businesses. Findings from the analysis indicated that the COVID-19 pandemic's effect includes: loss of competent staff resulting from reduction in staff salary, low revenue or income generation, lack of patronage, and lack of sincerity on the part of government to reduce the prevalence of the pandemic. The SMEs are often faced with problems such as: inability to pay salaries, repay loans and rent. Most respondent suggested that government should introduce a well monitored and structured palliative schemes, poverty alleviation programs, reduced interest rates, relax loans and defer tax payments. There are related variables that were not mentioned in this study. It is therefore necessary to consider them in future research work.
\end{abstract}

\section{Keywords}

COVID-19, Pandemic, Lockdown, Business Performance, SMEs, Abuja-FCT

\section{Introduction}

In the history of the world, infectious diseases have wreaked havoc among coun- 
tries. The continuous and emerging global convergence is also influencing the speed of the spread of these infectious diseases. According to the World Health Organisation (WHO), the world has witnessed emergence of several disease outbreaks and epidemics caused by more than 20 infectious agents over the past decade. The emergence of coronavirus-associated diseases (SARS and MERS) inflicted global challenges to public health systems. SARS-CoV-2 (the causative agent for coronavirus disease COVID-19) is the latest addition to this expanding list of novel agents. WHO declared COVID-19 a public health emergency of international concern on 30 January 2020 and a pandemic on 11 March 2020.

Bogoch et al. (2020) report indicated a clustering pneumonia of unknown aetiology in Wuhan, China: potential for international spread via commercial air travel. It is adjudged as to be one of the worst pandemics in human history with a staggering number of more than 1.4 million infections in 177 countries and more than 85000 deaths globally as at 9th April, 2020.

The quick and successive spread of this virus called COVID-19 pandemic all over the world has meted huge and unprecedented difficult time in history. It became prevalent and began extending virally to the whole world with attendant contraction in the global economy.

The virus was discovered in Nigeria in February 2020. It spread to some cities namely: Lagos, Ogun and FCT. The continual spread of the pandemic led to partial lock down of these cities in the first instance and later, a total lockdown of the whole country in March 2020.

The emergence of COVID-19 pandemic brought about changes worldwide including Nigeria. The changes are summarised as: increased sickness, death, poverty, effect on health, food production, security, money supply, reduced inflow of foreign exchange resulting from lack of export and import of goods and services except for essential products, lack of patronage resulting from restrictions in movement and access, changes in mode of business operation from physical contact to online and many others. The SMEs suffered and are still being affected by the emergence of the pandemic since year 2020. Patronage and cashflow of the SMEs evaluated was seriously impacted by the novel virus plaguing the world economy. This experience triggered negative survival, excitement and sentiment on the continuous infection of this pandemic. Businesses have collapsed and many more are on the verge of extinction due to prevalence of COVID-19 pandemic. Hence, most SMEs with insufficient capital outlay went into economic shock and it is highly unlikely to recover from this shock in the short run.

The various hardship caused by this novel virus informed many countries in the world to enforce containment measures which led to the restrictions on movements nationally and internationally, total lock down and closure of business activities, border to border movement restrictions among others.

As SMEs are vital to economic growth and also contribute to the development of the world economy generally and specifically in developing economies, the 
SMEs play major role in economic development as employers of labour. Abosede \& Onakoya, 2013; Aderemi et al. (2020) summarised that, the SMEs in Nigeria play pivotal role in the economic development resulting from their capacity to stimulate welfare of the people, reduction of unemployment and productivity. Bloom et al. (2001) indicated that health is a key player and a driving force that brings prosperity through economic growth and development. Therefore, absence of good health system and a healthy business environment, business activities cannot thrive successfully. Bloom et al. (2001) earlier noted that pandemics pose negative impacts on economic performance, through poor health.

The prevalence of COVID-19 has instigated various researches in economics, health, environment, manufacturing, agriculture and many more. It is expected that these research work will postulate possible coping strategies or mechanisms and guidelines that will mitigate against future effect of pandemic on SMEs and world economy.

Brounen and Derwall (2010); Hon, Strauss and Yong (2004); Karolyi (2006) likened the effects of pandemics to terrorist attack, which inhibit trade and business activities within affected areas, and has the capacity to lower productivity. Srivastava \& Agarwal (2020) indicated that the pandemic has posed the greatest impact on stock markets around the globe, and has caused worst economic meltdown since the 2008 global financial crisis. In recent times, Goodell (2020) agrees that natural disasters and terrorist attacks are similar to the effects of COVID-19 on economic performance, because it inhibits trade and production within places affected. Financial Times (2020) attests to this, noting that the emergence of COVID-19 has created panic in the financial system, causing high volatility in several markets. Akhtaruzzaman et al. (2020) affirms by stressing that many financial and non-financial firms across the globe have been adversely affected by the COVID-19 pandemic, as stock returns are trending downwards these days. Busari and Jaiyeoba (2021) noted that even if the pandemic is resolved, its effects on business and economic performance will linger in the short run.

This study is interrogated by the researcher to elicit government sensitivity in ensuring medium- and long-term planning in health sector are made and reviewed periodically so that whenever SMEs are confronted with pandemics or shock of this nature in the future, they will be able to surmount it and avoid any possible future economic shock. Despite this global effect on the finances of SMEs, the following businesses experienced boom; Telecommunication, Medicaments and medical equipment, businesses involved in the production and supply of essential products, fumigation, decontamination and defogging service providers.

For the purpose of this study, the prospect and games theories were reviewed because of its relativity to the research study.

This study is limited to identifying the cause, source or origin of COVID-19 
pandemic, actual number of people that contacted the virus, accurate number of deaths, veracity of claim on the ravenous nature of the virus, empirical and theoretical claim to buttress the argument about the effect or impact of corona virus on the global economy, the possible coping strategies and palliative measures suitable to alleviate the effect of the virus prevalence on SMEs business operation. In addition, the sample size is a limitation because it is only a representative of the SMEs operating business in Abuja Municipal Area Council (AMAC).

This study is organised as follows; Chapter 1 (introduction, statement of problem, research objectives, research questions, statement of hypothesis, and significance of the study), Chapter 2 (Context and literature review: Contextual framework, empirical review and theoretical framework, Chapter 3 (Methodology), Chapter 4 (Presentation, analysis, and discussion of findings), Chapter 5 (Conclusion and Recommendation), Chapter 6 (Area of further research).

\subsection{Statement of Problem}

There are many infectious diseases in the history of the world, but the COVID-19 has proven to be highly infectious, viral and contagious. The effect of this infection on human life is highly unprecedented. This has led to many operators of SMEs to close down business operation, social distancing, and also total compliance to lockdown directives by the Federal Government of Nigeria. The effect of this containment measures also led to a negative effect on the cashflow, supplies, revenue, and lack of patronage on SMEs businesses generally and specifically in Abuja, Nigeria. In addition, the containment measures such as; total lock down, restrictions on movement affected production level, reduced sales, reduced revenue, caused cash trap, hunger, illness, death, unemployment, poverty among others. These challenges hampered the performance of SMEs in the world at large and specifically on SMEs performance in Abuja since prevalence of COVID-19 pandemic. The effect of these on SMEs spurred many researchers to commence in-depth study into identifying and defining coping strategies and measures that policy makers, institution and many other stakeholders can adopt in order to avoid similar effect in the future.

The following authors made meaningful contributions into effect of COVID-19 Pandemic on SMEs business performance in Nigeria. They are: Aderemi et al. (2020) - "the Impact of Corona Virus (COVID-19) Pandemic on Small and Medium Scale Enterprises (SMEs) in Nigeria”, Akingbade (2021) — “the challenges of COVID-19 pandemic on Micro, Small and Medium Scale Enterprises in Nigeria”, Otache (2020)_-"the effects of Covid-19 Pandemic on Nigeria's economy and possible coping strategies", and Oyewale et al. (2020) also provided insight in "Estimating the impact of COVID-19 pandemic on Small and Medium Scale Enterprises: Evidence from Nigeria”.

In the publication of UNDP, 2020, it was reported that many businesses and countries in the world are facing severe financial and economic crises resulting 
from the prevalence of Covid-19 Pandemic.

As proclaimed by Albert Einstein: "Amid every crisis lies great opportunity" for managers, the Covid-19 crisis creates an opportunity to foster transiliency and thus better cope with the next Pandemic (Craighead et al., 2020).

\subsection{Research Objectives}

The key objective of the study is to examine the effect of COVID-19 pandemic on the performance of SMEs in Abuja. The specific objectives are:

1) To highlight the effect of lock down on the financial performance of SMEs business in Abuja.

2) To determine the effect of COVID-19 infection on the financial performance of SMEs business in Abuja.

3) To determine the coping strategies for the financial performance of SMEs business in Abuja.

\subsection{Research Questions}

The following research questions were raised in line of the statement of the problem and research objectives.

1) To what extent has lock down affect financial performance of SMEs business in Abuja?

2) To what extent has COVID-19 infection affected financial performance of SMEs business in Abuja?

3) How can the coping strategies ameliorate financial performance of SMEs business in Abuja?

\subsection{Statement of Hypotheses}

The following null hypotheses were raised in line with the research questions and hypotheses to guide the study.

1) $H_{01}$ : There is no significant relationship between lock down and financial performance of SMEs in Abuja.

2) $H_{02}$ : There is no significant relationship between COVID-19 infection and financial performance of SMEs in Abuja.

3) $\mathrm{H}_{03}$ : The coping strategy has no effect on financial performance of SMEs in Abuja.

\subsection{Significance of the Study}

The study will be of great significance to both policy makers and SMEs in general. Specifically,

- to the policy makers, it would provide the basis for effective policies for the sector's survival of the covid-19 challenges and also adopt strategies to mitigate likely future occurrence.

- to the SMEs, it would provide an opportunity for diversification, business 
opportunities and coping strategies now and in the near future.

\section{Context and Literature Review}

\subsection{Conceptual Review}

Towards the end of 2019, an infectious and viral disease code named: COVID-19 became prevalence. The emergence of this novel virus was not evidentially traceable, but was adjudged to have emanated from a clustering pneumonia of unknown aetiology in Wuhan city, a district in China. This un-identifiable virus spread virally to other part of the globe without frontier. The medical experts claimed that COVID-19 affects the entire respiratory system of the body by collapsing the lungs first which leads to shortness of breath and eventual collapse of all functional organs of the body.

In March, 2020, COVID-19 was discovered in Nigeria and the following states; Lagos, Ogun and FCT fell to record early casualties of the pandemic. The record provided by NCDC mid-November 2020 indicated many cases of patients that contacted COVID-19 and death rates.

In other to contain the spread of the virus, the federal government instituted several measures, including a complete lockdown in the nation. This measure became a major constraint to business and specifically, SMEs due to; restrictions of movement, ban on market places, transport restriction and social distancing order.

Therefore, since SME business operations play vital roles in economic growth and development, efforts should be made to ensure that they do not collapse or go into extinction. Hence, the need to provide social protection approaches and other palliative measures by the Federal Government of Nigeria.

Therefore, the prevalence and spread of COVID-19 like wild fire is still a mirage and novel to the world. In view of this, effort has been made to present reviewed studies of previous researchers in this study area. These are explained below:

Aderemi et al. (2020) submitted that COVID-19 spread to Africa as by-product of globalization while examining the nexus between globalization and Covid-19 pandemic vis-à-vis Africa and China. Del Rio et al. (2020) examined the impact of COVID-19 pandemic on stock market value of China, Europe and USA with an application of differential analysis. The authors submitted that COVID-19 pandemic exacted different impacts in the stock markets the regions under study.

In Abayomi et al. (2021) in a survey reported that many micro enterprises in the thirty-six states of the country were operating negatively and being affected by the pandemic particularly in the area of cashflow, revenue and sales.

Following various authors conceptual review, the researcher has made efforts to present a conceptual relationship between the independent variable, the proxies that indicated the effect of COVID-19 on depended variable and as shown in Figure 1 below which presents this study's conceptual framework: 


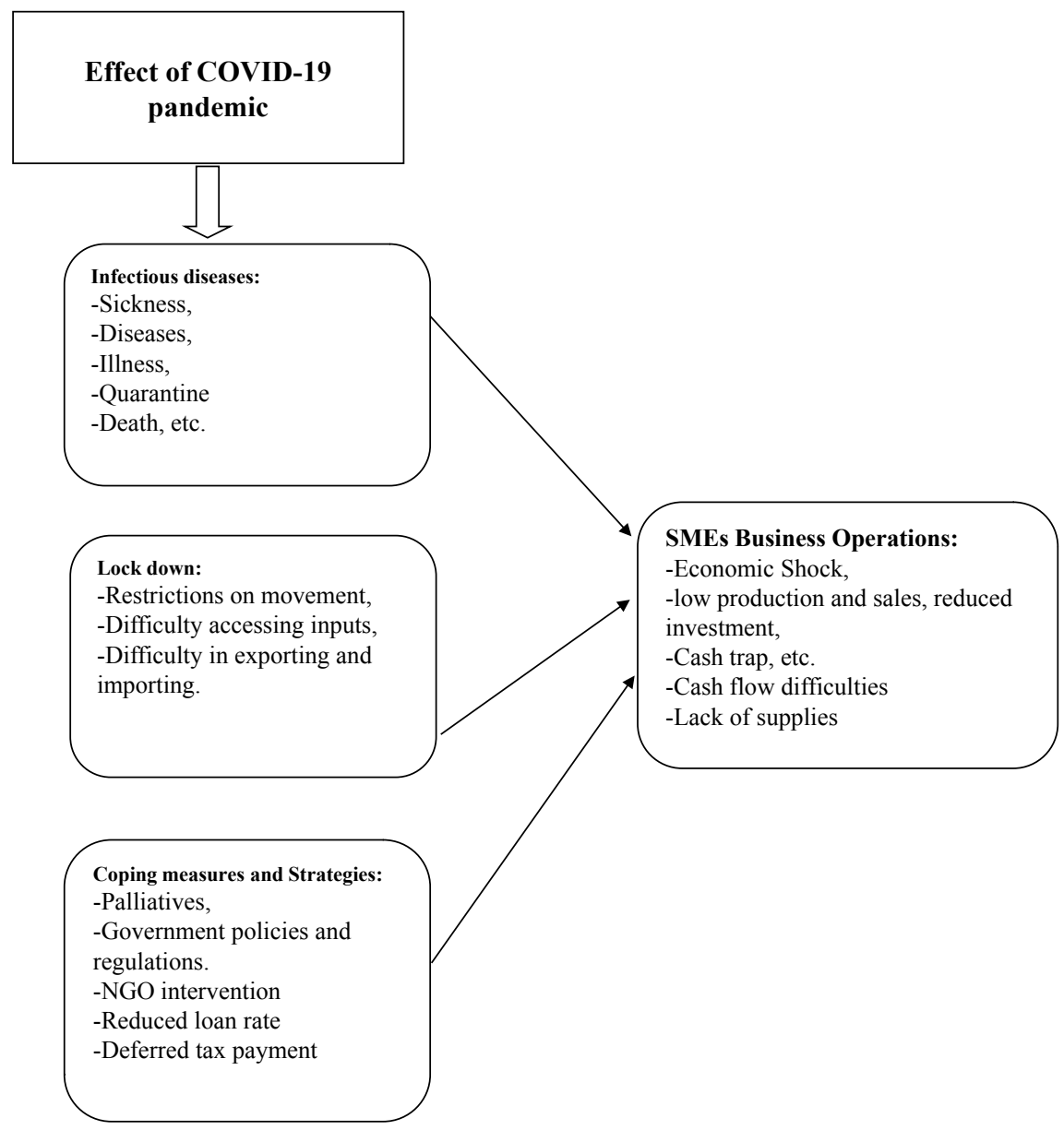

Figure 1. Study’s conceptual framework. Source: Author’s design 2021.

\subsection{Empirical Review}

This section of the study presents a review of previous studies that empirically tested the relationship between effects of COVID-19 pandemic on the performance of SMEs business in Nigeria. Many researchers have conducted studies around the world since the emergence of COVID-19 pandemic with devastating effect on the world economy and have mostly affected the operations and performance of small and medium enterprises. Some of the reviews of previous studies are highlighted below:

First, the study of Okey-Colbert et al. (2020) indicated that, despite the contributions of SMEs to the economic development and growth in Nigeria, it has been confronted with different challenges such as; low skilled manpower, multiplicity of statutory levies, fares, and incremental expenses of operating businesses. The SMEs are characterized by low productivity, limited access to financial resources and a negligible role in global value chains and the trading system. Obviously, growth in business is a measure of performance, hence, without growth, SMEs operations cannot be sustained or have sufficient capacity to confront crisis since most of the SMEs are already in comatose. Businesses cannot get supply of the goods they buy because most of them are majorly imported from China. 
Since most of these SMEs operate on a day-to-day level, their investments for the first half of this year 2020 have all but washed down the drain. Supply and demand challenges have led to an inability to meet loan and lease repayment schedules. As the overall volume of production falls and cash starts to run out, some SMEs have already had to down size their staff strength, and some non-essential staff were relieved of their jobs.

Secondly, Abideen (2020) provided an insight of the effect of COVID-19 pandemic on the performance of SME business and its survival in a research study in Nigeria. The result of the study revealed the significant negative relationship with the SMEs performance.

Following the negative effect COVID-19 pandemic is posing to the business performance of SMEs in Nigeria, most of them are reducing staff strength in order to cope with the overhead expenses, revenue is decreasing and declining geometrically, defaults in the repayment of loans are also being recorded due to inadequate cash inflow. Ironically, most of the SMEs are reducing staff strength, revenue is decreasing geometrically, defaults in the repayment of loans are being recorded.

There are many researches ongoing that are yet to unravel or explore the empirical performance of SMEs and more specifically on business owners in some part of Nigeria. It is on this premise that the author decided to examine the effect of COVID-19 pandemic on the performance of SMEs in Nigeria with specific emphasis on SMEs operating businesses in Abuja.

\subsection{Theoretical Framework}

Many theories relating to economic shock, terrorism and pandemic have been postulated. Some of which are; real options theory, events systems theory, resource dependency theory, institutional theory, structural inertia, resources or orchestrated theory, Prospect theory and Game theory Craighead et al. (2020) elicited the relevance of games theory in decision making by SMEs during pandemic of this nature. Two theories related to this research study namely: prospect and Games theories are reviewed.

\section{1) Prospect theory}

Tversky \& Khneman, 1992 submitted that prospect theory becomes relevant and useful for decision making during uncertainty. It is often an advantage to present situation positively than on a negative term (Craighead et al., 2020), which leads to the selection of riskier options. Prospect theory facilitates prediction into the near future about how a manager will react under a pandemic situation.

\section{2) Game theory}

This is also a prediction theory (Von Neumann \& Morgenstern, 2007) posited that games theory uses a set of rules and guidelines on how stakeholders respond to situation and information while relating or interacting with one another. Games theory assumes selfish choices are made during one-time interaction. But Bo, 2005 submitted that, continuous relationship among stakeholders will lead to cooperation, knowing fully well that selfish act will lead to future retaliation. 
Games theory has been applied to the adoption of new technology (Zhu \& Weyant, 2003), decisions on distribution channels (Xia, Xiao, \& Zhang, 2013) and production quantities and optimal pricing (Gao et al., 2013). Based on the assumptions of Game theory, firms with the objectives of competing are likely to cooperate during Pandemic because of the implication of the high cost of defection (Craighead et al., 2020).

\section{Methodology}

This study was carried out in Abuja Municipal Area Council (AMAC), Abuja, Nigeria. It adopted a survey research design using a structured questionnaire to solicit opinion of the respondents and to understand the effect of COVID-19 pandemic on the performance of SMEs business in Abuja. These questionnaires were distributed amongst selected SMEs within AMAC in FCT, Abuja. The data collected was within two weeks in May, 2021. A total number of 100 questionnaires were distributed at the ratio of 10 respondents in each of the 10 different SMEs, 96 questionnaires were returned but out of the numbers returned, 16 questionnaires were actually defaced or not properly filled. Only 80 viable questionnaires were analysed.

Data for the study were obtained through the primary source with the aid of questionnaire which is both open and close ended. The data was presented using bar chart with the aid of simple percentage for the analysis, while chi-square was used to test the hypothesis. The sampling technique adopted for this study is a random sampling technique.

\section{Presentation, Analysis and Discussion of Findings}

The structured questionnaire was distributed randomly by hand to various respondents within the selected SMEs in AMAC. Specifically, the questions focused on effects of lock down, the impact of COVID-19 on revenue and performance of business, employment levels and awareness of government policy to support their business. Findings from the questionnaire are presented in bar chart below:

1) Has your business being in operation since March 2020 ?

From Figure 2, 25\% of the respondents accepted the fact that their business has been in operation since March 2020, while 75\% of the respondent said No.

2) Was there lockdown where you have your SME?

Figure 3 shows that $94 \%$ of the respondents affirmed that there was full lockdown in their area of SMEs while 6\% said they had partial lockdown.

3) Was the stay-at-home order compliance?

Whether people comply with the order of stay-at-home or not, Figure 4 shows there was $88 \%$ full compliance while $12 \%$ observed partial compliance.

4) Can you cope with your income and savings?

From Figure 5, 94\% of the firms responded that they cannot cope with their income and savings because of the pandemic while only $6 \%$ responded that they can cope. 


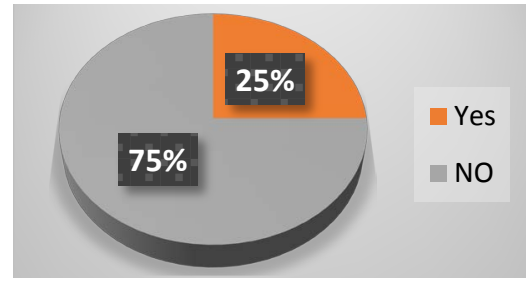

Figure 2. Responses to SMEs to business operation since March, 2020.

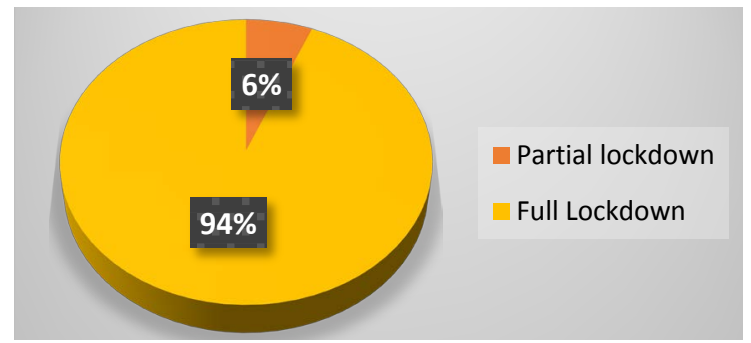

Figure 3. Responses of SMEs on the presence of lockdown in business operation environment.

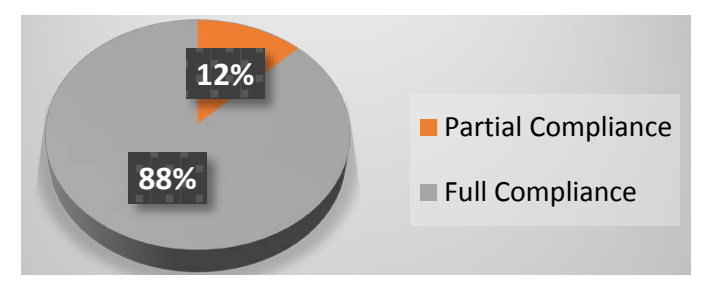

Figure 4. Response from SMEs on compliance rating.

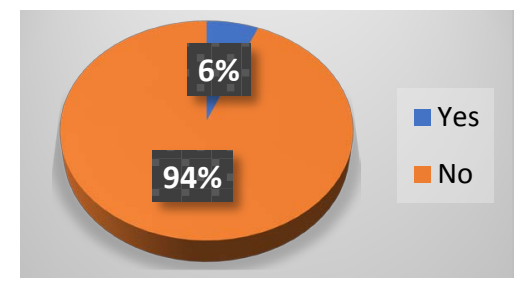

Figure 5. Responses of SMEs on reliance on income and savings.

5) What coping strategy will your company employ in case the lockdown is extended?

About coping strategy that will be employed by the firms if the lockdown is extended, $25 \%$ said they are going to borrow from friends and family, 37\% said they will obtain loan from banks, $13 \%$ said they will by goods and services on credit while another $25 \%$ said they will sell their assets (Figure 6).

6) Assuming the lockdown was extended beyond the initial timeline, are you sure your company can cope financially?

If the lockdown was extended, Figure 7 shows the response of the respondents on whether their firms can cope financially. 19\% said it is not applicable to their business while $12 \%$ said they can cope financially, in contrast, $69 \%$ said they cannot cope. 


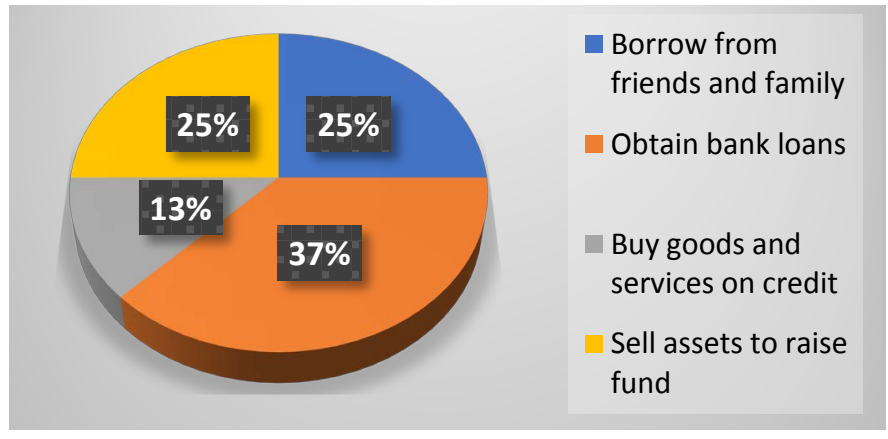

Figure 6. Responses of SMEs on the type of coping strategies to adopt.

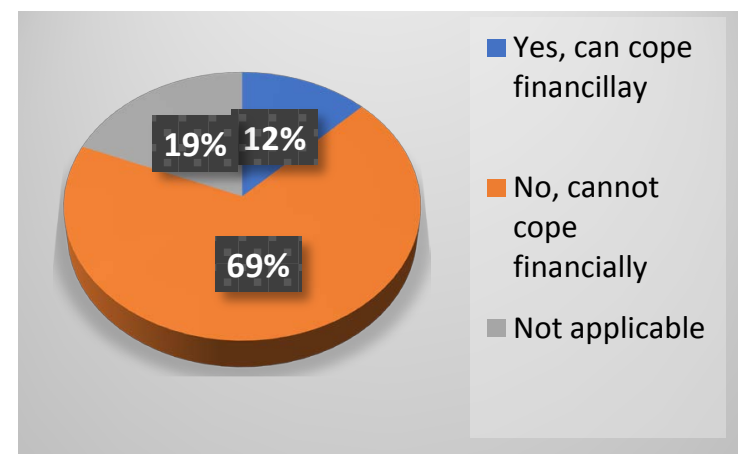

Figure 7. Responses of SMEs on the possibilities of coping financially should the lockdown be extended.

7) In overall, can you rate the government's palliative measures on the scale of $1-5$ rates ( 5 is the highest)

As for the rating of government's palliative measures on the scale of $1-5$, Figure 8 shows that $63 \%$ of the respondents asserted that the measures are very poor, $31 \%$ said it was just poor while $6 \%$ said it was fair.

8) To what extent has COVID-19 affected the operations of your business?

The extent at which the COVID-19 pandemic has affected the operations of SMEs business in Abuja is shown in Figure 9, 6\% said they were affected to a little extent while absolute majority of $94 \%$ said they were greatly affected. Nobody claimed he was not affected and nobody with no response.

9) What is the expected time for the company's business recovery?

Following up with the effects of COVID-19 on the performance of SME business, $19 \%$ of the respondents affirmed that it will take them 1 month to 3 months before they could recover while $25 \%$ said it will be more than 3 months. The larger percentage of $56 \%$ said they are unable to judge or predict the time of recovery (Figure 10).

In addition, findings from the analysis of the null hypothesis are presented below:

\section{Testing Hypothesis}

Formula for Chi-Square $=X^{2}=\sum \frac{\left(F_{o}-F_{e}\right)^{2}}{F_{e}}$ 


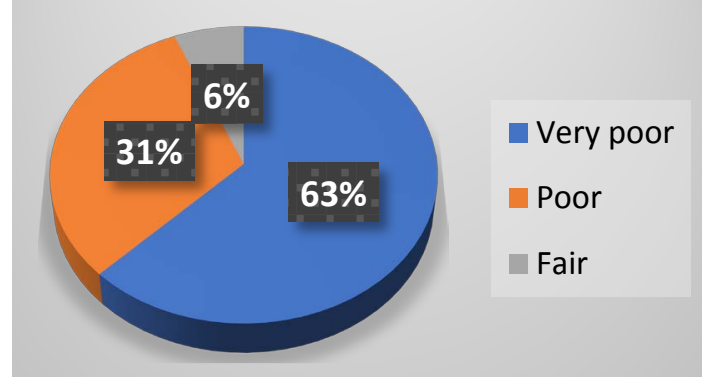

Figure 8. Responses from SMEs on the rating of government palliatives.

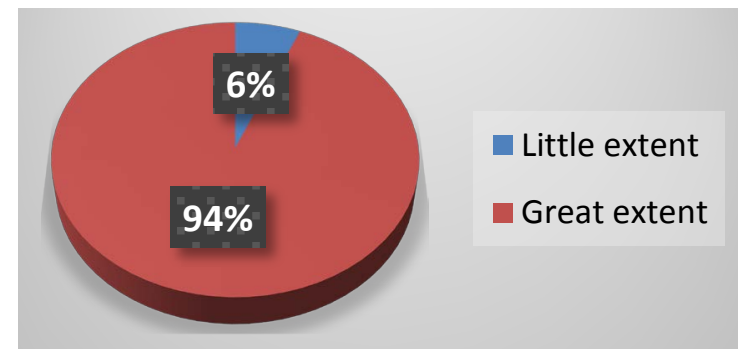

Figure 9. Responses of SMEs on the extent of the effect of COVID-19 pandemic on business operation.

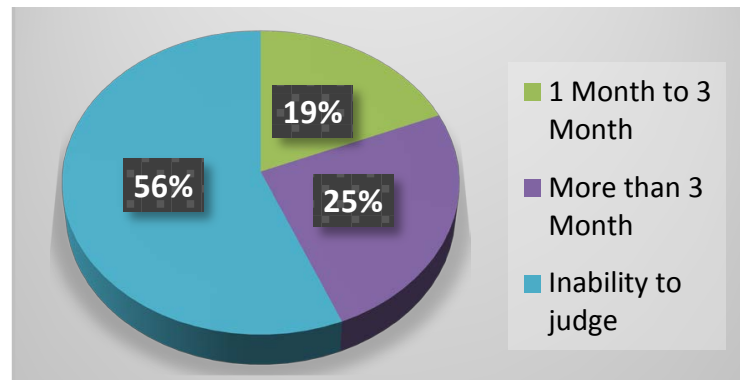

Figure 10. Responses of SMEs on the possible timeline for business recovery.

$n=$ Total Sum of the Variables (80)

$F_{o}=$ Observed Variables

$F_{e}=$ Expected Variables

$X^{2}=$ Symbol of Chi-Square

Decision Rule: At 5\%, when the calculated value is greater than the table value (2), we reject the Null and Accept the Alternate Hypothesis.

1) Hypothesis for research question one:

Observed Variables $\left(F_{o}\right)$ are already given, we need to derive the Expected Variables $\left(F_{e}\right)$

Therefore: $F_{e}=$ Total Sum of the Variables (80)/Total number of the Variables: $80 / 3=26.67$.

Calculated Value: 83.1

Table Value: 2

The calculated Value 83.1 is more than the Table Value 2; therefore, we reject $H_{o}$ and Accept $H_{i}$. 
$H_{i}=$ There is a significant relationship between lockdown and performance of SME business in Abuja (Table 1).

\section{2) Hypothesis for Research Question Two}

$N=$ Total sum of the Variables (80)

Observed Variables $\left(F_{o}\right)$ are already given, we need to get the Expected Variables $\left(F_{e}\right)$.

$F_{e}=$ Total Sum of the Variables (80)/Total number of the Variables: 80/4 $=20$.

Calculated Value: 202.5

Table Value: 2

The calculated Value 202.5 is more than the Table Value 2; therefore, we reject $H_{o}$ and Accept $H_{i}$.

$H_{i}$. There is a significant relationship between COVID-19 infections and performance of SMEs business in Abuja (Table 2).

\section{3) Hypothesis for Research Question Three}

$N=$ Total sum of the Variables (80)

Observed Variables $\left(F_{o}\right)$ are already given, we need to get the Expected Variables $\left(F_{e}\right)$.

$F_{e}=$ Total Sum of the Variables (80)/Total number of the Variables: 80/4 $=20$.

Calculated Value: 64.69

Table Value: 2

The calculated Value 64.69 is more than the Table Value 2; therefore, we reject $H_{o}$ and Accept $H_{i}$.

$H_{i}$ : The coping strategy has effects on the performance of SMEs business in Abuja (Table 3).

Table 1. The extent lock down affect financial performance of SMEs.

\begin{tabular}{cccccc}
\hline Sources & $F_{o}$ & $F_{e}$ & $F_{o}-F_{e}$ & $\left(F_{o}-F_{e}\right)^{2}$ & $\left(F_{o}-F_{e}\right)^{2} / F_{e}$ \\
\hline So much Strain on the Income & 65 & 26.67 & 38.33 & 1469.2 & 55.1 \\
A little strain on the income & 5 & 26.67 & -21.67 & 469.6 & 17.6 \\
No strain on the Income & 10 & 26.67 & -16.67 & 277.9 & 10.4 \\
TOTAL & 80 & & & & 83.1
\end{tabular}

Table 2. The significant relationship between COVID-19 infection and financial performance of SMEs.

\begin{tabular}{cccccc}
\hline Sources & $F_{o}$ & $F_{e}$ & $F_{o}-F_{e}$ & $\left(F_{o}-F_{e}\right)^{2}$ & $\left(F_{o}-F_{e}\right)^{2} / F_{e}$ \\
\hline Little Extent & 5 & 20 & -15 & 225 & 11.25 \\
Great Extent & 75 & 20 & 55 & 3025 & 151.25 \\
Not affected & 0 & 20 & -20 & 400 & 20 \\
No response & 0 & 20 & -20 & 400 & 20 \\
TOTAL & 80 & & & & 202.5
\end{tabular}


Table 3. The coping strategies or measures having no effect on financial performance of SMEs in Abuja.

\begin{tabular}{cccccc}
\hline Sources & $F_{o}$ & $F_{e}$ & $F_{o}-F_{e}$ & $\left(F_{o} F_{e}\right)^{2}$ & $\left(F_{o} F_{e}\right)^{2} / F_{e}$ \\
\hline $\begin{array}{c}\text { Supplies from Federal Government and State } \\
\text { Government through Local Government }\end{array}$ & 5 & 26.67 & 21.67 & 469 & 17.61 \\
$\quad$ Supplies from NGOs & 0 & 26.67 & -26.67 & 711.3 & 26.67 \\
Supplies from Creditors & 50 & 26.67 & 23.33 & 544.3 & 20.41 \\
TOTAL & 60 & & & & 64.69 \\
\hline
\end{tabular}

From the foregoing, the study revealed that COVID-19 pandemic has seriously impacted negatively on the performance and existence of SME business in Nigeria. Considering variables such as; lockdown, movement restrictions, closure of markets and social distancing to measure the effect of COVID-19 pandemic on the performance of SMEs in Abuja, Nigeria. Most of the variables had a positive and significant effect of COVID-19 pandemic on the performance of SMEs business. Therefore, these findings can be linked or associated to that carried out by Macias Gil et al. 2020.

\section{Conclusion and Recommendations}

\subsection{Conclusion}

The prevalence of Covid-19 pandemic will definitely change the dynamics of doing business worldwide. While the prospects for many SMEs may look discouraging and morale damaging in this period, the world economy will eventually rebound with successive businesses springing up. It is advisable now for SMEs to assess the damages their companies may face and strategically address protection measures that will assist in mitigating the impact of the pandemic while maximizing the opportunities that will most certainly present themselves once the pandemic is contained.

\subsection{Recommendation}

From this study, it is obvious that COVID-19 pandemic is causing severe disaster than good to business worldwide. Therefore, decisive measures should be in place to keep and maintain business that is at the verge of extinction and total collapse. Despite the palliatives being provided by the Nigerian government tagged "COVID-19 relief packages" to provide support to SMEs, the following recommendations were derived:

1) Government review of monetary and fiscal policies measures,

2) Ensuring effective and efficient palliative measures are established by the government, NGOs and organisations,

3) Adoption of E-Business model to business.

\section{Areas for Further Research}

This research study intends to carry out further research on the following areas 
of identified gaps:

1) The impact of COVID-19 on SMEs in selected states within the six geo-political zones of Nigeria,

2) The impact of government palliative measures on SMEs operation in Nigeria during COVID-19 pandemic,

3) Identifying SMEs preferences on government assistance in order to facilitate performance,

4) Identifying the most significant financial problems of SMEs during the COVID-19 outbreak,

5) The Impact of financial institutions intervention on SMEs operation in $\mathrm{Ni}$ geria,

6) The level of preparedness of health institutions to mitigate against any future pandemic that may affect the operations of SMEs in Nigeria,

7) Any other related issues that will add value to this study.

\section{Conflicts of Interest}

The authors declare no conflicts of interest regarding the publication of this paper.

\section{References}

Abayomi, A., Angioha, P. U., \& Abang, T. (2021). Covid 19 Pandemic and Entrepreneurship Enterprise in Calabar, Cross River State, Nigeria. Journal of Good Governance and Sustainable Development in Africa, 6, 23-29.

Abideen, S. O. (2020). Coronavirus (COVID-19) and the Survival of Small and Medium Enterprises in Abeokuta, Ogun State Nigeria. Scholars Journal of Economics, Business and Management, 7, 209-214. https://doi.org/10.36347/sjebm.2020.v07i06.002

Abosede, A. J., \& Onakoya, A. B. (2013). Entrepreneurship, Economic Development, and Inclusive Growth. International Journal of Social Sciences and Entrepreneurship, 1, 375-387.

Aderemi, T. A., Ojo, L. B., Ifeanyi, O. J., \& Efunbajo, S. A. (2020). Impact of Corona Virus (COVID-19) Pandemic on Small and Medium Scale Enterprises (SMEs) in Nigeria: A Critical Case Study. Acta Universitatis Danubius. Economica, 16, 251-261.

Akhtaruzzaman, M., Boubaker, S., Chiah, M., \& Zhong, A. (2020). COVID-19 and Oil Price Risk Exposure. Finance Research Letters, Article ID: 101882. https://doi.org/10.1016/j.frl.2020.101882

Akingbade, W. A. (2021). COVID-19 Pandemic Challenges to Micro, Small and Medium Enterprises in Nigeria: Strategic Options for Survival. Acta Economica, 19, 153-167. https://doi.org/10.7251/ACE2134153A

Bloom, D. E., Canning, D., \& Sevilla, J. P. (2001). The Effect of Health on Economic Growth: Theory and Evidence. NBER Working Paper No. w8587.

https://ssrn.com/abstract $=290389$

https://www.nber.org/papers/w8587

Bogoch, I. I., Watts, A., Thomas-Bachli, A., Huber, C., Kraemer, M. U., \& Khan, K. (2020). Pneumonia of Unknown Aetiology in Wuhan, China: Potential for International Spread via Commercial Air Travel. Journal of Travel Medicine, 27, taaa008.

Brounen, D., \& Derwall, J. (2010). The Impact of Terrorist Attacks on International Stock 
Markets. European Financial Management, 16, 585-598. https://doi.org/10.1111/j.1468-036X.2009.00502.x

Busari, I. A., \& Jayeoba, A. O. (2021). COVID-19 and Strategies for Business Survival in Nigeria: Empirical Analysis.

Craighead, C. W., Ketchen Jr., D. J., \& Darby, J. L. (2020). Pandemics and Supply Chain Management Research: Toward a Theoretical Toolbox. Decision Sciences, 51, 838-866. https://doi.org/10.1111/deci.12468

Del Rio, C., Collins, L. F., \& Malani, P. (2020). Long-Term Health Consequences of COVID-19. JAMA, 324, 1723-1724. https://doi.org/10.1001/jama.2020.19719

Gao, H. N., Lu, H. Z., Cao, B., Du, B., Shang, H., Gan, J. H., Li, L. J. et al. (2013). Clinical Findings in 111 Cases of Influenza A (H7N9) Virus Infection. New England Journal of Medicine, 368, 2277-2285. https://doi.org/10.1056/NEJMoa1305584

Goodell, J. W. (2020). COVID-19 and Finance: Agendas for Future Research. Finance Research Letters, 35, Article ID: 101512. https://doi.org/10.1016/j.frl.2020.101512

Hon, M. T., Strauss, J., \& Yong, S. K. (2004). Contagion in Financial Markets after September 11: Myth or Reality? Journal of Financial Research, 27, 95-114.

Karolyi, G. A. (2006). The Consequences of Terrorism for Financial Markets: What Do We Know? https://ssrn.com/abstract $=904398$

Macias Gil, R., Marcelin, J. R., Zuniga-Blanco, B., Marquez, C., Mathew, T., \& Piggott, D. A. (2020). COVID-19 Pandemic: Disparate Health Impact on the Hispanic/Latinx Population in the United States. The Journal of Infectious Diseases, 222, 1592-1595. https://doi.org/10.1093/infdis/jiaa474

Nigerian Economy at Risk of "Unravelling”, Warns World Bank. Financial Times. https://www.ft.comcontent/

Okey-Colbert, E. U., Chinakwe, P. C., \& Aguwamba, I. J. (2020). Emerging Challenges and Opportunities of the Coronavirus (COVID-19) Pandemic for Small and Medium Enterprises (SMEs) in Nigeria. Maiden Virtual International Conference, 27th-28th August 2020, 249.

Otache, I. (2020). The Effects of the Covid-19 Pandemic on the Nigeria's Economy and Possible Coping Strategies. Asian Journal of Social Sciences and Management Studies, 7, 173-179. https://doi.org/10.20448/journal.500.2020.73.173.179

Oyewale, A., Adebayo, O., \& Kehinde, O. (2020). Estimating the Impact of COVID-19 on Small and Medium Scale Enterprise: Evidence from Nigeria.

Srivastava, S., \& Agarwal, N. (2020). Psychological \& Social Effects of Pandemic Covid-19 on Education System, Business Growth, Economic Crisis \& Health Issues Globally. An International Journal of Management \& IT A Refereed Research Journal, 11, 40-45. https://doi.org/10.46360/globus.mgt.120201007

Tversky, A., \& Kahneman, D. (1992). Advances in Prospect Theory: Cumulative Representation of Uncertainty. Journal of Risk and Uncertainty, 5, 297-323.

https://doi.org/10.1007/BF00122574

Von Neumann, J., \& Morgenstern, O. (2007). Theory of Games and Economic Behaviour. Princeton University Press.

Xia, Y., Xiao, T., \& Zhang, G. P. (2013). Distribution Channel Strategies for a Manufacturer with Complementary Products. Decision Sciences, 44, 39-56. https://doi.org/10.1111/j.1540-5915.2012.00381.x

Zhu, K., \& Weyant, J. P. (2003). Strategic Decisions of New Technology Adoption under Asymmetric Information: A Game-Theoretic Model. Decision Sciences, 34, 643-675. https://doi.org/10.1111/j.1540-5414.2003.02460.x 